\title{
Pollination techniques in zucchini production in the presence of boron fertilization
}

\author{
Sara Neves Pagoto ${ }^{(0}$, Alessandra de Almeida Laudete ${ }^{\circledR}$, Gabriel de Jesus Neves ${ }^{(}$ \\ Lucas de Abreu Degaspari ${ }^{(}$, Lourismar Martins Araujo ${ }^{\left({ }^{\circ}\right.}$, Fabrício Ribeiro Andrade*(i)
}

Federal Institute of Education, Science and Technology of Mato Grosso, Cuiabá, Brazil

${ }^{*}$ Corresponding author, e-mail: fabricio.andrade@jna.ifmt.edu.br

\begin{abstract}
Zucchini (Curcubita pepo L.), known in Brazil as "abóbora de moita", belongs to the Cucurbitaceae family and is among the top ten vegetables produced and of highest economic value in Brazil. The present study aims to evaluate the efficiency of different forms of pollination in zucchini plantations subject to boron fertilization. The experimental design used was randomized blocks in a $4 \times 2$ factorial arrangement, with four replications. The treatments consisted of a combination of four pollination methods (fruiting induced with 2,4-dichlorophenoxyacetic acid (2,4-D); manual pollination; natural pollination by bees and control) and boron fertilization (absent and in the soil at a dose of $2 \mathrm{~kg} \mathrm{ha}^{-1}$ ). The percentage of flowering was evaluated and, of the harvested squashes, the diameter, length and average weight of the commercial fruits (those uniform in terms of shape, size, and color) were recorded. The application of 2,4-D promoted the greatest fruit setting rate, diameter, length and mass in the squash. 2,4-D promoted the development of parthenocarpic fruits and can be used to promote yield gains in zucchini production.
\end{abstract}

Keywords: Curcubita pepo L., parthenocarpic, 2,4-dichlorophenoxyacetic acid pollen, absence of bees

\section{Introduction}

The zucchini (Curcubita pepo L.), known in Brazil as "abóbora de moita", belongs to the Cucurbitaceae family and is among the top ten vegetables produced and of highest economic value in Brazil (Fernandes et al., 2016). The plants of this species are annual, with a bushy growth habit, allogamous and with monoecious flowering (Kumar et al., 2016). They have solitary yellowish flowers, the female ones being less numerous (Lim, 2015). The fruits are small $(3.5-8.0 \mathrm{~cm}$ in diameter), light green, elongated, with rounded ends and usually have thin, dark green, longitudinal stripes (Paris, 2016). The plant can be harvested between 40 and 60 days after planting.

According to Lim (2015) pollination and fruit establishment are entomophilic, that is, dependent on insects. Bees of the species Apis mellifera L. are considered the main pollinators of Cucurbitaceae (Vidal et al., 2010; Delgado-Carrillo et al., 2018). However, other species such as Melipona quadrifasciata Lep.; Bombus morio (Swederus, 1787); Trigona hyalinata (Lepeletier, 1836) and Trigona spinipes (Fabr.) also have the ability to efficiently pollinate squash flowers (Serra \& Campos, 2010). However, intense changes in the natural environment, such as the destruction of forests and the nesting sites of various pollinators, the chemicals used in agriculture and exotic animal introduction have led to drastic reductions of their populations (Delgado-Carrillo et al., 2018; Serra \& Campos, 2010).

Among the alternatives to solve the pollination deficit of several commercial plant species are manual pollination and parthenocarpic reproduction, in which fruiting is chemically induced by auxin group phytoregulators which, sprayed on the stigma, guarantee fruit formation (Pasqualetto et al., 2001).

Additionally, chemical elements such as boron (B) may intervene with the phytoregulators in the process 
of pollen grain fertilization and germination. Boron acts on several plant metabolic processes, mainly on pollen grain fertility and pollen tube elongation, reducing the disruption possibility. The absence of this leads to a decrease in the formation of flower buds, flowers and, consequently, irregular fruit development (Franzon \& Raseira, 2006; Nogueira et al., 2015). Studies have shown that the addition of boron was also beneficial in the germination of pollen for pear (Chagas et al., 2010), blackberry (Figueiredo et al., 2013) and loquat (Nogueira et al., 2015), but studies addressing the use of this nutrient in squash production are incipient.

Thus, studies aimed at evaluating the efficiency of different forms of pollination in the cultivation of zucchini, given boron fertilization, are extremely relevant. Especially since there are no such studies for zucchini. Therefore, the objective of the present study is to evaluate the efficiency of different forms of pollination for zucchini, with or without boron fertilization.

\section{Material and Methods}

The study was conducted in the experimental olericulture area of the Federal Institute of Education, Science and Technology of Mato Grosso (IFMT), Juína campus (1 1 $26^{\prime} 55^{\prime \prime}$ S; 5843'24" W; 320m altitude), from May to July 2019. The experimental area soil is classified as Red Oxisol, which has a loamy clay texture and a gently undulating relief. The region's climate is characterized by an average annual rainfall of 1,900 $\mathrm{mm}$ and an average annual temperature of $24^{\circ} \mathrm{C}$. The minimum, average and maximum temperatures, along with air humidity are shown in Figure 1.

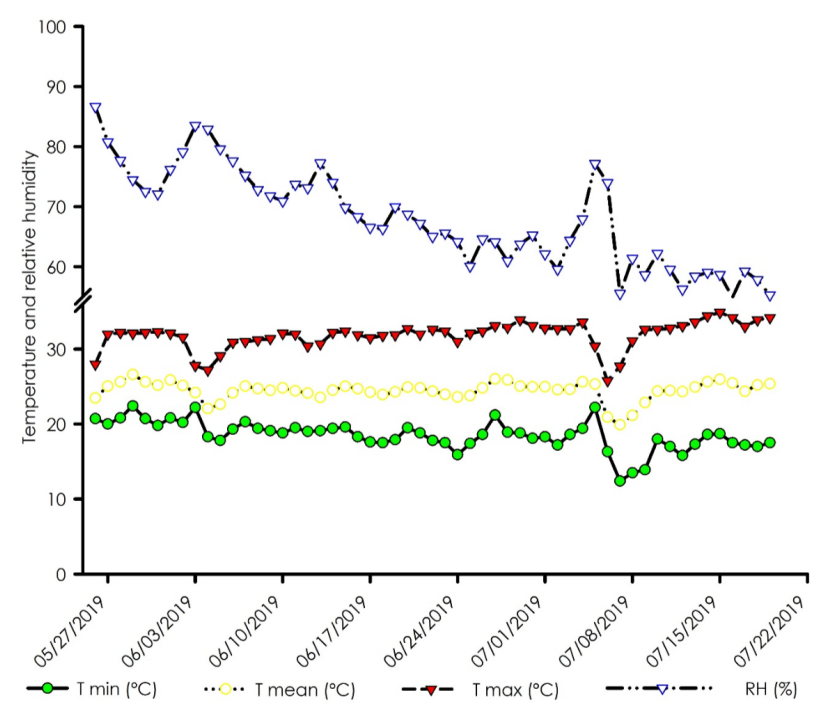

Figure 1. Minimum ( $\mathrm{T} \mathrm{min}$ ), mean ( $\mathrm{T}$ mean), and maximum ( $T$ max) temperatures and relative humidity (RH) over the experimental period in Juína, MT, Brazil. Source: INMET network data.
The soil of the experiment had the following chemical characteristics: $\mathrm{pH}$ in $\mathrm{H}_{2} \mathrm{O}=7.0 ; \mathrm{MO}=30.8 \mathrm{~g}$ $\mathrm{dm}^{-3} ; \mathrm{P}$ (resin) $=6.1 \mathrm{mg} \mathrm{dm}{ }^{-3} ; \mathrm{K}^{+}=0.33 \mathrm{cmol}_{\mathrm{c}} \mathrm{dm}^{-3} ; \mathrm{Ca}^{2+}$ $=4.4 \mathrm{cmol}_{\mathrm{c}} \mathrm{dm}^{-3} ; \mathrm{Mg}^{2+}=1.35 \mathrm{cmol}_{\mathrm{c}} \mathrm{dm}^{-3} ; \mathrm{H}^{+}+\mathrm{Al}^{3+}=1.57$ $\mathrm{cmol}_{\mathrm{c}} \mathrm{dm}^{-3} ; \mathrm{Al}^{3+}=0.05 \mathrm{cmol}_{\mathrm{c}} \mathrm{dm}^{-3} ; \mathrm{S}=5.01 \mathrm{mg} \mathrm{dm}^{-3} ;$ clay $=$ $380 \mathrm{~g} \mathrm{~kg}^{-1}$; silt $=100 \mathrm{~g} \mathrm{~kg}^{-1}$ and sand $=520 \mathrm{~g} \mathrm{~kg}^{-1}$.

The experimental design was a randomized complete block design in a $4 \times 2$ factorial arrangement with four replications. The treatments consisted of four pollination methods combination (2,4-D induced fruiting; manual pollination; natural pollination by bees and control) and boron fertilization (absent and via soil at a dose of $2 \mathrm{~kg} \mathrm{ha}^{-1}$ ). The pollination methods were conducted eight times during the zucchini crop life cycle. More specifically, the zucchini cultivar "Antonella" hybrid F1 (from Feltrin Seeds Company) was used in this study.

In the treatment of induced fruit set (PAR-I), the female flowers were protected during the pre-anthesis phase to avoid bee pollination. In the anthesis, the flowers were unprotected, their stigmas sprayed with a solution of 2,4-dichlorophenoxyacetic acid $(2,4-D)$ at a concentration of $160 \mathrm{mg} \mathrm{L}^{-1}$ and protected again. In full manual pollination (MP), female flowers were isolated in the pre-anthesis, uncovered in the anthesis and a mixture of pollen from the male flowers was homogeneously deposited on all stigmatic lobes of the female flowers. After pollen was deposited, the flowers were again isolated.

In the treatment group naturally pollinated (NP) by bees, the flowers were isolated in the pre-anthesis phase and uncovered to allow visitation by pollinating agents during the anthesis phase. In the control group (PAR-N), the female flowers were isolated in the preanthesis phase and remained so, without any contact with pollinating agents or fruiting inducers. The purpose of this control group was to determine the incidence of natural parthenocarpy.

Each plot consisted of four plants spaced 0.80 $\times 1.00 \mathrm{~m}$ between rows and between plants within rows, respectively. Chemical fertilization consisted of $130 \mathrm{~kg} \mathrm{ha}^{-1}$ nitrogen (N), $300 \mathrm{~kg} \mathrm{ha}^{-1} \mathrm{P}_{2} \mathrm{O}_{5}$ and $120 \mathrm{~kg} \mathrm{ha}^{-1} \mathrm{~K}_{2} \mathrm{O}$ (Trani et al., 2014). All phosphorus and $30 \% \mathrm{~N}$ and potassium (K) were applied at planting. The remaining $N$ and $K$ were divided into two applications at 25 and 40 days after germination. The B was applied before planting, using boric acid. Weed control was carried out through hand weeding up to 25 days after sowing. The plants were drip irrigated throughout the cycle according to the water needs of the crop.

One week after the application of the treatments, 
the percentage of fruit-bearing flowers was calculated, and the zucchinis were harvested. Of these fruits, those of commercial- grade were selected and their diameter, length, and average mass were measured. Fruits that are uniform in shape, size, and color are considered of commercial grade.

The normality of all the data sets was analyzed using the Anderson-Darling test and their homoscedasticity was analyzed using the variance equation test (or Levene's test). The data obtained for each variable were subjected to variance analysis $(p \leq 0.05)$ and the factors were compared using the Scott-Knott test ( $p \leq 0.05)$. The statistical program $R$ version 3.2.3 was employed for the statistical analysis of the data.

\section{Results and Discussion}

The boron application did not influence the evaluated parameters but presented significance for all fruiting treatments (Table 1). No interaction effect was observed between boron application and fruiting treatments. Boron plays an important role in pollen germination and pollen tube growth (Liu et al., 2013). However, soil availability is strongly influenced by soil $\mathrm{pH}$, where boron availability is adequate between a $\mathrm{pH}$ of 6.0 and 7.0 (Fageria \& Nascente, 2014). This explains the absence of effects of the boron application, since the current $\mathrm{pH}$ may have promoted the maximum availability of micronutrients to the plants.

Table 1. Variance analysis ( $F$ values) of different treatments on growth and fruiting variables for zucchini in Juína, MT, Brazil.

\begin{tabular}{lcccc}
\hline \multicolumn{1}{c}{ SV } & RS & FD & FL & FM \\
\hline Blocks & $1.10^{\text {ns }}$ & $2.35^{\text {ns }}$ & $1.97^{\text {ns }}$ & $3.54^{*}$ \\
Boron (B) & $2.82^{\text {ns }}$ & $1.99^{\text {ns }}$ & $0.33^{\text {ns }}$ & $0.37^{\text {ns }}$ \\
Pollination methods (PM) & $45.31^{* *}$ & $809.46^{* *}$ & $487.97^{* *}$ & $150.87^{* *}$ \\
B x PM & $0.45^{\text {ns }}$ & $0.42^{\text {ns }}$ & $0.40^{\text {ns }}$ & $0.35^{\text {ns }}$ \\
\hline CV (\%) & 29.90 & 6.74 & 8.56 & 15.97 \\
*and ** significant to 1 and 5\% respectively; ns - not significant. SV: sources of variation; CV: coefficient of variance; RS: rate of fruit setting; FD: fruit diameter; FL: fruit length; &
\end{tabular}

The highest fruit setting rate (64.25\%) was observed in the induced fruiting treatment (Figure 2A) with the application of 2,4-D. Nomura et al. (2019) verified that the application of 2,4-D to the female flower of the hybrid variety "Tetsukabuto" promoted the fruiting of $69.48 \%$ of the sprayed flowers, a value very close to that found in this study. The application of 2,4-D increased the fruit setting rate by $26 \%$ and $58.50 \%$ for manual pollination and natural pollination by bees, respectively. The lower pollination rates of flowers subjected to natural pollination may be related to the lack of synchronization between the opening of the first male flowers and the first female flowers of the same plant (Pedrosa et al., 1982). Furthermore, the absence of pollinating insects at the opening time of these flowers may have hindered pollination. The flowers open between 6 am and 11 am, which is when their stigma is most receptive to crossover (Dmitruk \& Weryszko-Chmielewska, 2013; Pasqualetto et al., 2001).

None of the flowers of isolated plants set, which shows no natural parthenocarpy (Figure 2A). Parthenocarpic fruits develop without seed formation, which makes their production viable in places where pollinating insects are scarce, like greenhouses, and when there is no flower synchronization (Cardoso \& Silva, 2003). In this sense, auxin group phytoregulators can replace the use of pollen sources as a means to guarantee and increase the fruit number in the zucchini production.
The zucchini flowers fruit sprayed with 2,4-D had an average diameter of $6.48 \mathrm{~cm}$, while natural pollination by bees and manual pollination produced fruits with diameters $20 \%$ and $15 \%$ smaller (Figure 2B). Queiroga et al. (2017) also verified increases of $11.6 \%$ in the diameter of fruits for the hybrid variety "Tetsukabuto" when 2,4-D was applied.

The longest fruit length $(19.8 \mathrm{~cm})$ was found in the treatment group of $2,4-D$ induced parthenocarpy, producing fruits $2.9 \%$ and $9.5 \%$ longer than those produced by manual pollination and natural bee pollination, respectively (Figure $2 \mathrm{C}$ ). The results found in the present study disagree with those found by Queiroga et al. (2017), who verified a reduction in the fruit length of the hybrid variety "Tetsukabuto" when 2,4-D was applied. Fruit diameter and length are relevant commercial attributes as smaller fruits are generally preferred by consumers. Given the results of this study, to obtain smaller fruit from the 2,4-D treatment group, the plants would be subject to earlier harvests.

The highest fruit mass (448.7 g) was observed in the induced fruiting treatment (Figure 2D) with the application of 2,4-D, which was significantly higher than other treatments. Fruits produced with the 2,4-D treatment were $21 \%$ and $42 \%$ heavier than those produced with manual pollination and natural bee pollination, respectively (Figure 2D). The results of the present study corroborate the findings of Miranda et al. (2017), Nomura 
et al. (2019) and Pereira et al. (2012), who all verified increases in fruit mass for 2,4-D treatment groups relative to plants not treated with 2,4-D.

The application of synthetic auxins, such as 2,4 dichlorophenoxyacetic acid, generates parthenocarpic fruits (devoid of seeds), which develop in the absence of fertilization. Synthetic auxin replaces the endogenous


Figure 2. Rate of fruit setting (A), diameter (B), length (C) and mass (D) of the fruit, dependent on the treatments of induced parthenocarpy with 2,4-D (PAR-I), manual pollination (MP), natural pollination (NP) and the occurrence of natural parthenocarpy (PAR-N) in zUcchini.

\section{Acknowledgements}

The authors express their thanks to CNPq (National Council for Scientific nd Technological Development Brazil), Fapemat (Foundation for Research Support of the State of Mato Grosso - Brazil) and the IFMT (Federal Institute of Education, Science and Technology of Mato Grosso - Brazil) for providing scholarships and financial support.

\section{References}

Cardoso, A.I.I., Silva, N. 2003. Avaliação de híbridos de pepino tipo japonês sob ambiente protegido em duas supply of fertilized ovary auxin necessary for fruit development, leading to increases in all the parameters evaluated. This practice allows for improved productivity in zucchini plantations, increasing the producer's revenue due to a higher percentage of setting fruit and an earlier harvest.
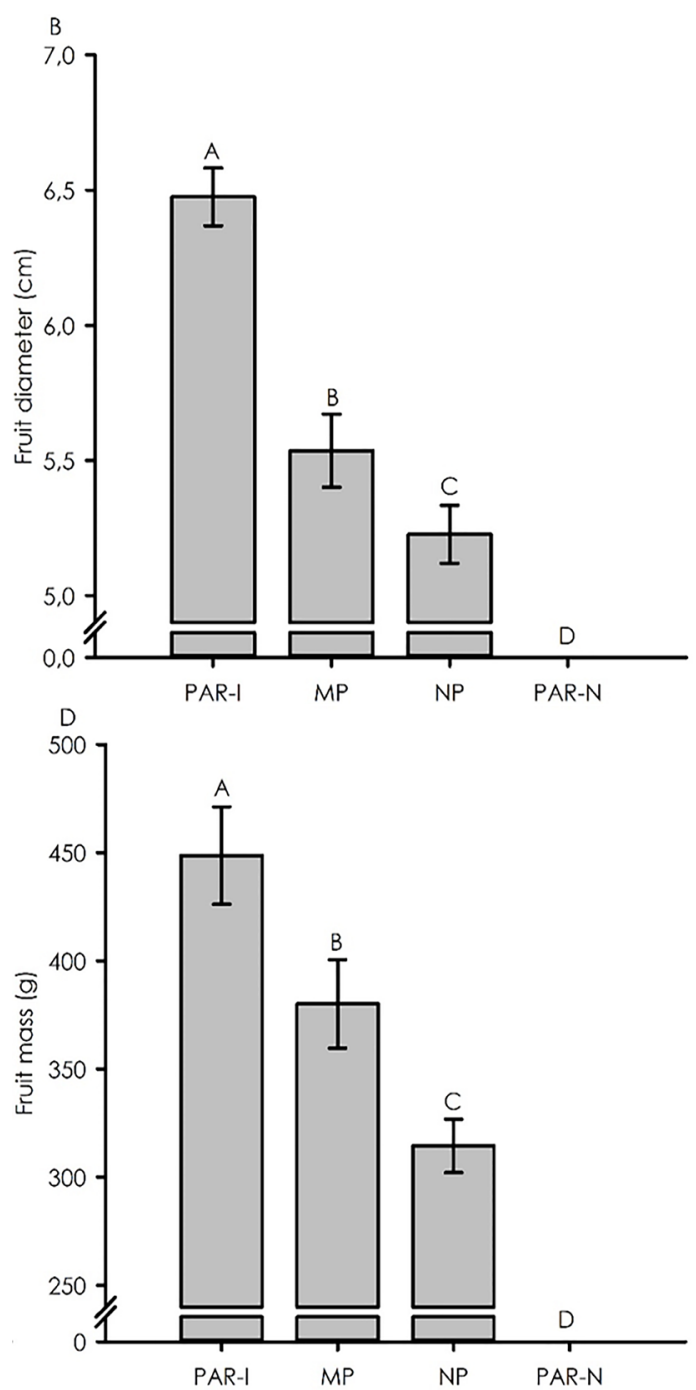
marrow (Cucurbita pepo L. convar. giromontiina). Acta Agrobotanica 66: 11-22.

Fageria, N.K., Nascente, A.S. 2014. Management of soil acidity of South American soils for sustainable crop production. Advances in Agronomy 128: 221-275.

Fernandes, C.N.V., Azevedo, B.M., Camargo, D.C., Dias, C.N., Rebouças Neto, M.O., Costa, F.R.B. 2016. Potassium fertilizer applied by different methods in the zucchini crop. Revista Brasileira de Engenharia Agrícola e Ambiental 20: 643-648.

Figueiredo, M.A., Pio, R., Silva, T.C., Silva, K.N. 2013. Características florais e carpométricas e germinação in vitro de grãos de pólen de cultivares de amoreira-preta. Pesquisa Agropecuária Brasileira 48: 731-740.

Franzon, R.C., Raseira, M.C.B. 2006. Germinação in vitro e armazenamento do pólen de Eugenia involucrata DC (Myrtaceae). Revista Brasileira de Fruticultura 28: 18-20.

Kumar, S., Rattan, P., Samnotra, R.K. 2016. Squashes and Gourds. In: Pessarakli, M. (Org.) Handbook of Cucurbits: Growth, Cultural Practices, and Physiology. CRC Press Taylor \& Francis, New York, USA. p. 513-532.

Lim, T.K. 2015. Edible medicinal and non-medicinal plants. Springer Netherlands, Dordrecht, Netherlands. 1100 p.

Liu, L.; Huang, L.; Li, Y. 2013. Influence of boric acid and sucrose on the germination and growth of Areca pollen. American Journal of Plant Sciences 4: 1669-1674.

Miranda, F.F.R., Nascimento, I.R., Chaves, P.P.N., Muraishi, C.T., Dourado, D.P. 2017. Agronomic characteristics of pumpkin fruits of "Tetsukabuto" hybrid as a function of 2,4-D doses. Comunicata Scientiae 8: 521-525.

Nogueira, P.V., Silva, D. F., Pio, R., Silva, P.A.O., Bisi, R.B., Balbi, R.V. 2015. Germinação de pólen e aplicação de ácido bórico em botões florais de nespereiras. Bragantia 74: 9-15.

Nomura, M., Franco, H.P., Costa, E.M., Nunes, B.M., Rocha, E.M.F. 2019. Produção de frutos partenocárpicos de abóbora híbrida "Tetsukabuto" sob aplicação de 2,4D. Revista Científica Rural 21: 215-225.

Paris, H.S. 2016. Germplasm enhancement of Cucurbita pepo (pumpkin, squash, gourd: Cucurbitaceae): progress and challenges. Euphytica 208: 415-438.

Pasqualetto, A., Silva, N.F., Ordonez, G.P., Barcelos, R.W. 2001. Produção de frutos de abóbora híbrida pela aplicação de 2,4-D nas flores. Pesquisa Agropecuária Tropical 31: 23-27.

Pedrosa, J.F., Alvarenga, M.A.R., Ferreira, F.A., Casali, V.W.D. 1982. Abóboras, morangas e abobrinhas: cultivares e métodos culturais. Informe Agropecuário 8: 24-26.

Pereira, A.M., Silva, G.D., Almeida, R.R.P., Silva, A.B., Queiroga, R.C.F. 2012. Frutificação de abóbora Tetsukabuto sobe aplicação de doses de 2,4-D na época seca em Pombal-PB. Revista Verde de Agroecologia e
Desenvolvimento Sustentável 7: 38-43.

Queiroga, R.C.F., Silva, G.D., Pereira, A.M., Almeida, R.R.P., Silva, A.B. 2017. Yield and quality of the Tetsukabuto squash fruits induced with 2,4-D doses under dry conditions. Horticultura Brasileira 35: 271-277.

Serra, B.D.V., Campos, L.A.O. 2010. Polinização entomófila de abobrinha Cucurbita moschata (Cucurbitaceae). Neotropical Entomology 28: 153-159.

Trani, P.E., Passos, F. A., Araújo, H. S. 2014. Calagem e adubação da abobrinha italiana (de moita) (Cucurbita pepo), abóbora brasileira (Cucurbita moschata), moranga (Cucurbita maxima) e abóbora japonesa (hibrida). IAC, Campinas, Brazil. 8 p. (Informações Tecnológicas).

Vidal, M.G., Jong, D., Wien, H.C., Morse, R.A. 2010. Pollination and fruit set in pumpkin (Cucurbita pepo) by honey bees. Revista Brasileira de Botânica 33: 107-113.

Conflict of Interest Statement: The authors declare that the research was conducted in the absence of any commercial or financial relationships that could be construed as a potential conflict of interest.

All the contents of this journal, except where otherwise noted, is licensed under a Creative Commons Attribution License attribuition-type BY. 